\section{Meeting hints at thaw in relations between genome rivals}

Colin Macilwain, Washington

Genome assemblers from the private and public human genome sequencing projects finally met in peace at a workshop on 6 June, and found plenty of areas of common interest to discuss.

The much-heralded meeting initially promised as part of the truce between the rival genome projects announced on 26 June 2000 by President Bill Clinton (see Nature 405, 983-984; 2000) — took place on neutral territory, at the Howard Hughes Medical Institute's headquarters near Washington.

"The goal of the meeting is to try and move forward and find out what common goals we have," explained Gene Myers, a mathematician who helped to devise the gene-assembly programme used by Celera of Rockville, Maryland, for its private project. Myers co-chaired the meeting with David Haussler, a computer scientist at the University of California, Santa Cruz, who had a prominent role in the public genome project, which is led in the United States by the National Institutes of Health.

Participants at the meeting, including gene-assembly and annotation experts from both projects, agreed that future sequencing projects of large genomes are likely to use a combination of the wholegenome shotgun approach pioneered by Celera and the clone-by-clone approach used by the public genome project.

There was agreement that the particular nature of an organism's genome, and the uses to which it might be put, would determine the appropriate strategy. "My feeling is that one approach to genome sequencing does not fit all," said Evan Eichler of Case Western Reserve University at Cleveland, Ohio. Eichler said he hoped the meeting would mark "a new era of détente" between the private and public projects.

Researchers using the genome data asked for more effort from both projects to build on the draft sequences and to deal with the large error rates being encountered. "Right now, with both the Celera and the public data sets, it is difficult to tell the difference between an interesting variant and a mistake in the data," said Sean Eddy of Washington University in St Louis, Missouri.

The meeting was attended by Francis Collins, director of the National Human Genome Research Institute, and other leaders of the genome effort, but not by Craig Venter, president of Celera.

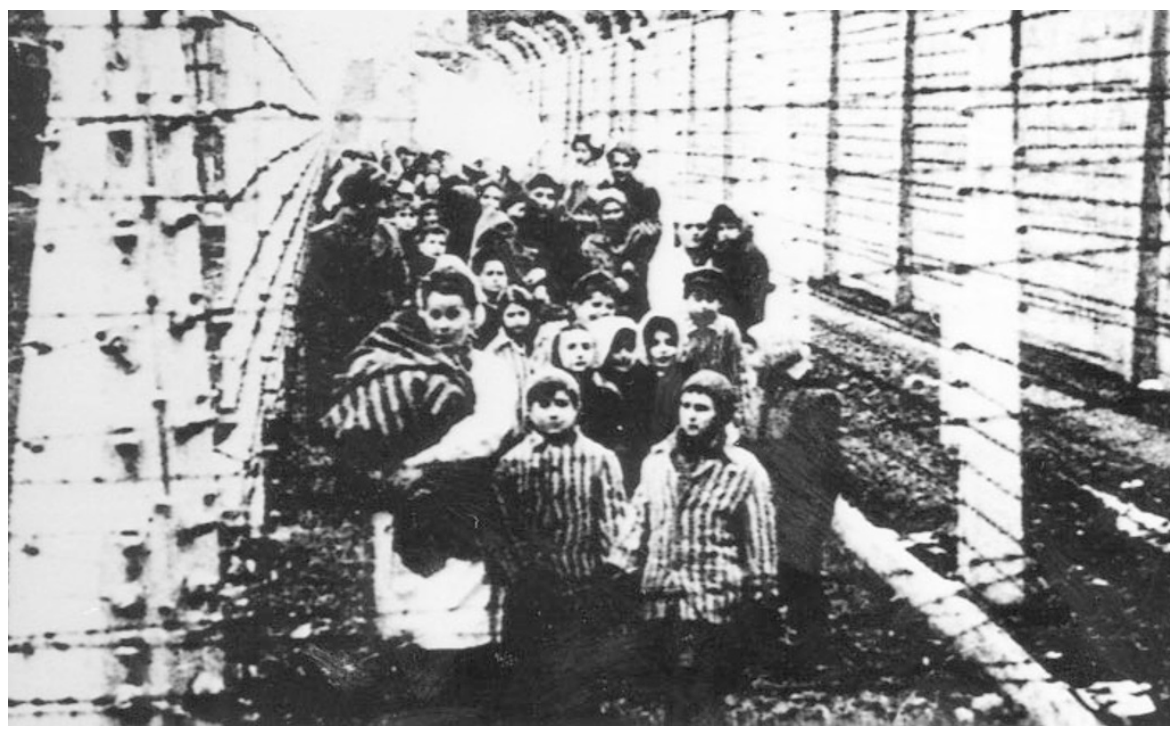

Eva Kor (left) and her twin sister Miriam lead out survivors following the liberation of Auschwitz.

\title{
Max Planck Society admits to its predecessor's Nazi links
}

Alison Abbott, Munich

Hubert Markl, president of the Max Planck Society (MPS), has accepted that the management and staff of its predecessor society were involved in Nazi war atrocities, and has apologized to their victims.

His statement was in response to the findings of a group of science historians he commissioned in 1999 to investigate the role played by basic researchers of the Kaiser Wilhelm Society during the Second World War. This society, which was succeeded after the war by the MPS, was responsible for medical experiments undertaken at concentration camps.

Markl has long resisted issuing what he said would be an 'easy apology' (see Nature 403, 813; 2000). But now, he says, the historians have produced hard evidence that proves "beyond the shadow of a doubt that directors and employees at Kaiser Wilhelm Institutes co-masterminded and sometimes even actively participated in the crimes of the Nazi regime".

His apology was delivered at an emotionally charged meeting held by the historians on 7 June in Berlin, at the halfway point of their five-year investigation.

Eva Mozes Kor, who with her twin sister Miriam was one of about 250 subjects who survived a programme of human experimentation orchestrated by the geneticist Josef Mengele at the Auschwitz concentration camp in Poland, told the meeting of her personal experiences.

Three times a week, Mengele's twins were walked to the Auschwitz main camp for experiments. "We had to sit naked in a room. Every part of our body was measured, poked and compared to charts and photographed. Every movement was noted. We were injected with germs and chemicals and they took a lot of blood from us," she said.

Kor said that her way of coping was to forgive the perpetrators. However, a second survivor, Jona Laks, said that the crimes should be remembered and never forgiven.

Kor explained how she developed a lifethreatening fever after one of the injections, and feigned recovery in order to rejoin the experiments. "Would I have died, Mengele would have killed Miriam with an injection to the heart and would have done comparative autopsies on our bodies. This is the way most of the twins died."

Markl said that his apology was not a request for "removal of guilt", as the crimes were too heinous to allow such a release. By apologizing, both personally and on behalf of the MPS in proxy for the Kaiser Wilhelm Society, Markl said: "I am referring to the sincerest expression of deepest regret, compassion, and shame at the fact that crimes of this sort were committed, promoted, and not prevented within the ranks of German scientists."

He also apologized for the fact that the MPS had taken so long to begin its investigation, which he claimed was partly due to "a lack of willingness on the part of [some] inside and outside the Max Planck Society to face up to their historical responsibility".

Kor, who was one of ten survivors present at the meeting and is a founder of the survivors' group Candles, called the apology a "courageous gesture".

http://www.candles-museum.com 